\title{
An electronmicroscope study of the effect of sulphadiazine and trimethoprim on Enterobacter cloacae
}

\author{
R. M. E. RICHARDS, J. Z. XING, D. W. GREGORY* and DEBORAH MARSHALL*
}

School of Pharmacy. The Robert Gordon University, Schoolhill, Aberdeen AB9 1FR and Department of Medical Microbiology, Medical School Buildings, Foresterhill, Aberdeen AB9 $2 Z D$

\begin{abstract}
Summary. Electronmicroscopy of thin sections of log phase cells of Enterobacter cloacae NCTC 10005 grown for $4 \mathrm{~h}$ in the presence of sulphadiazine $250 \mu \mathrm{g} / \mathrm{ml}$, trimethoprim $12.5 \mu \mathrm{l} / \mathrm{ml}$ or the combination of sulphadiazine $250 \mu \mathrm{g} / \mathrm{ml}$ plus trimethoprim $12.5 \mu \mathrm{g} / \mathrm{ml}$ indicated that both agents caused marked morphological damage even though the MIC of sulphadiazine for the $E$. cloacae strain was $>3000 \mu \mathrm{g} / \mathrm{ml}$. The damage took the form of electron-transparent areas devoid of ribosomes in the cytoplasm and detachment of the outer membrane. The latter was most marked with trimethoprim, which also caused damage to the cytoplasmic membrane. It is postulated that the synthesis of the peptidoglycan layer was affected by the antimetabolites since the morphological effects were strikingly similar to those caused by treatment of $E$. cloacae with disodium edetate plus lysozyme. Viable counts of cultures undergoing the same treatments as those prepared for electronmicroscopy indicated that although sulphadiazine merely partially inhibited growth it nevertheless enhanced the bactericidal action of trimethoprim over a 5 -h period.
\end{abstract}

\section{Introduction}

We have presented evidence recently that subinhibitory concentrations of trimethoprim and sulphonamides mutually enhance their uptake by bacteria. even when the bacteria are resistant to one member of the combination. ${ }^{1+4}$ Thus a strain of Enterohacter cloacae for which the MIC of sulphadiazine was $>3000 \mu \mathrm{g} / \mathrm{ml}$. and that of trimethoprim was $15 \mu \mathrm{g} / \mathrm{ml}$, was inhibited by a combination of sulphadiazine $100 \mu \mathrm{g} / \mathrm{ml}$ and trimethoprim $7.5 \mu \mathrm{g} / \mathrm{ml}$. The synergy correlated with markedly increased uptake of the two compounds. This provided an explanation for antibacterial synergy between sulphonamides and trimethoprim alternative to the sequential blockade of folate synthesis. Similar increases in the combined uptake of sulphadiazine and trimethoprim were obtained with two strains of Pseudomonas aeruginosa that were resistant to high concentrations of both antibacterial agents used alone. ${ }^{1}$

The purpose of the present investigation was to investigate the morphological effects of sulphadiazine and trimethoprim on log phase cells of E. cloacae, to clarify further our earlier findings. ${ }^{13}$ An additional objective was to determine whether the sulphadiazine could contribute to the bactericidal action of the combination against a strain that was highly resistant to the sulphonamide. It is well known that sulphonamides contribute to the bacteriostatic action of

Received 30 Dec. 1991: revised version accepted 16 June 1992 sulphonamide-trimethoprim combinations against sensitive bacteria, but there is considerable uncertainty as to whether they contribute to bactericidal synergy, especially if the bacteria are sulphonamide resistant. ${ }^{5-8}$

\section{Materials and methods}

E. cloacae NCTC 10005 was obtained from the National Collection of Type Cultures, Colindale Avenue, London. Sulphadiazine, trimethoprim and $p$-aminobenzoic acid were from Sigma.

\section{Sample preparation}

From an 18-h broth culture of E. cloacae $1 \mathrm{ml}$ was inoculated into $99 \mathrm{ml}$ of Iso-Sensitest Broth (Oxoid) at $37^{\circ} \mathrm{C}$ in a $250-\mathrm{ml}$ conical flask. The culture was shaken at 100 oscillations $/ \mathrm{min}$ in a water bath at $37^{\circ} \mathrm{C}$ for $4 \mathrm{~h}$; $10-\mathrm{ml}$ quantities of this $\log$ phase culture were then inoculated into $250-\mathrm{ml}$ conical flasks containing $90 \mathrm{ml}$ of Iso-Sensitest broth plus sulphadiazine $250 \mu \mathrm{g} / \mathrm{ml}$, or trimethoprim $12.5 \mu \mathrm{g} / \mathrm{ml}$, or both. A flask containing $90 \mathrm{ml}$ of Iso-Sensitest broth without an antibacterial agent was used as the control. These four flasks were incubated at $37^{\circ} \mathrm{C}$ for $4 \mathrm{~h}$ in a water bath with shaking (100 oscillations/min).

\section{Electronmicroscopy}

The cultures were centrifuged at $6000 \mathrm{~g}$ for $15 \mathrm{~min}$ at $4^{\circ} \mathrm{C}$. and the supernate was removed. The pellet was 

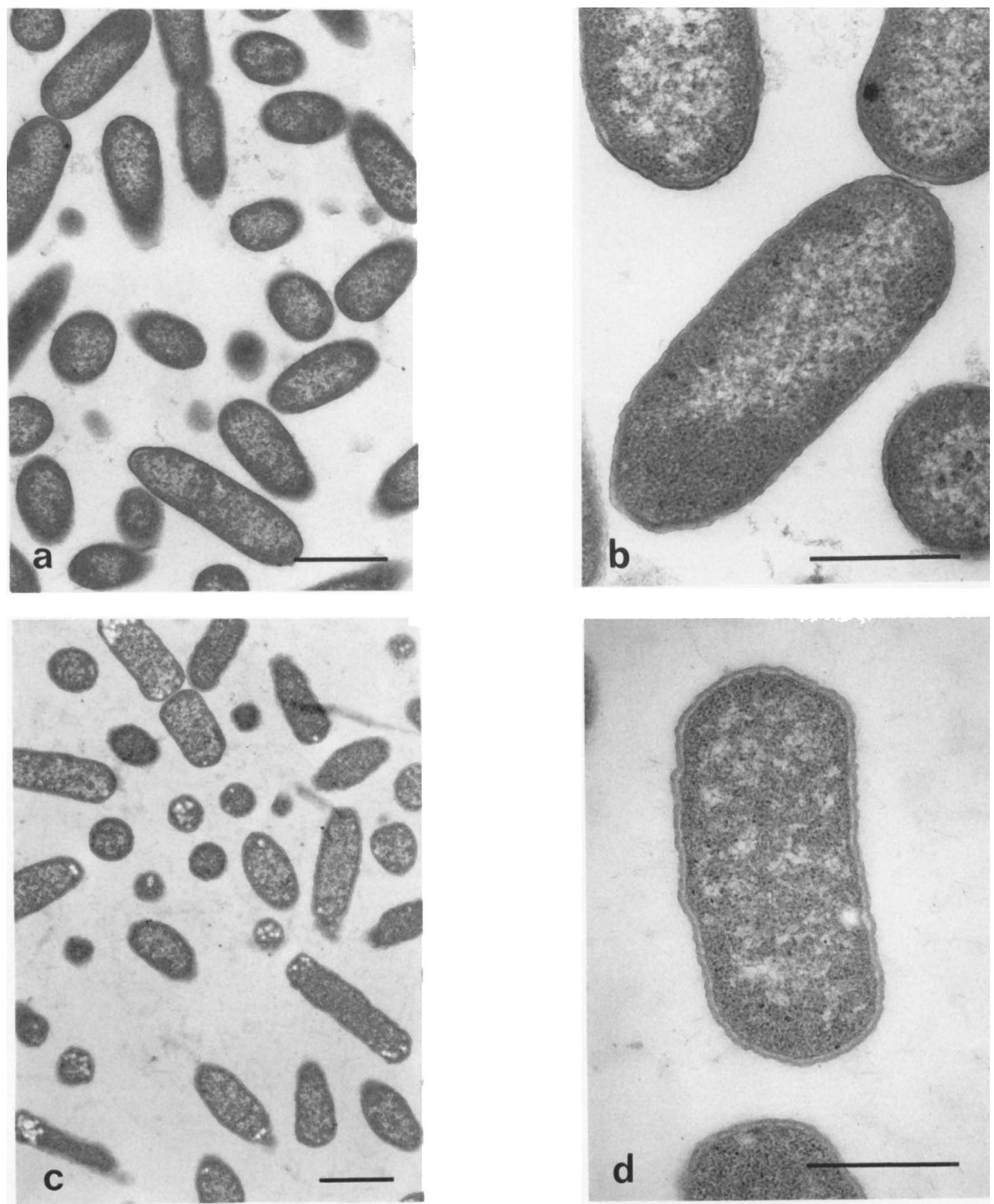

Fig. 1. Ultrathin sections of $\log$ phase E. cloacae NCTC 10005 grown in Iso-Sensitest broth. a, b, control (no antibacterial agent); $\mathbf{c}$, bacteria exposed to sulphadiazine $250 \mu \mathrm{g} / \mathrm{ml}$ for $4 \mathrm{~h}$. Bar $=1 \mu \mathrm{m}(\mathbf{a}, \mathbf{c}) ; 0.5 \mu \mathrm{m}(\mathbf{b}, \mathbf{d})$.

fixed in glutaraldehyde $8 \% \mathrm{v} / \mathrm{v}$ in $0.1 \mathrm{~m}$ phosphate buffer ( $\mathrm{pH} 7 \cdot 2$ ) for $1 \mathrm{~h}$, and then in glutaraldehyde $4 \%$ $\mathrm{v} / \mathrm{v}$ in $0.1 \mathrm{M}$ phosphate buffer $(\mathrm{pH} 7 \cdot 2)$ for $4 \mathrm{~h}$ at $4^{\circ} \mathrm{C}$. After washing in the same buffer the bacteria were resuspended in $\mathrm{OsO}_{4}$ (Emscope, Watford) $1 \% \mathrm{w} / \mathrm{v}$ for $1 \mathrm{~h}$ at room temperature. They were then washed three times by centrifugation and resuspension in distilled water. The final pellet was resuspended in a small volume of warm agarose $2 \% \mathrm{w} / \mathrm{v}$, poured on to a glass slide and allowed to cool. When set, small pieces of gel containing suspended bacteria were cut out and dehydrated through a graded series of ethanol solu- tions. After embedding in Araldite (Agar Scientific Ltd, Stansted, Essex) thin sections were cut with a diamond knife on a Reichert Ultracut $E$ ultramicrotome, stained with uranyl acetate and lead citrate, and examined in a Philips EM301 electronmicroscope operating at $80 \mathrm{kV}$.

\section{Treatment with disodium edetate plus lysozyme}

From a $\log$ phase culture of E. cloacae, 10-ml volumes were inoculated separately into three $250-\mathrm{ml}$ conical flasks each containing $90 \mathrm{ml}$ of IsoSensitest 

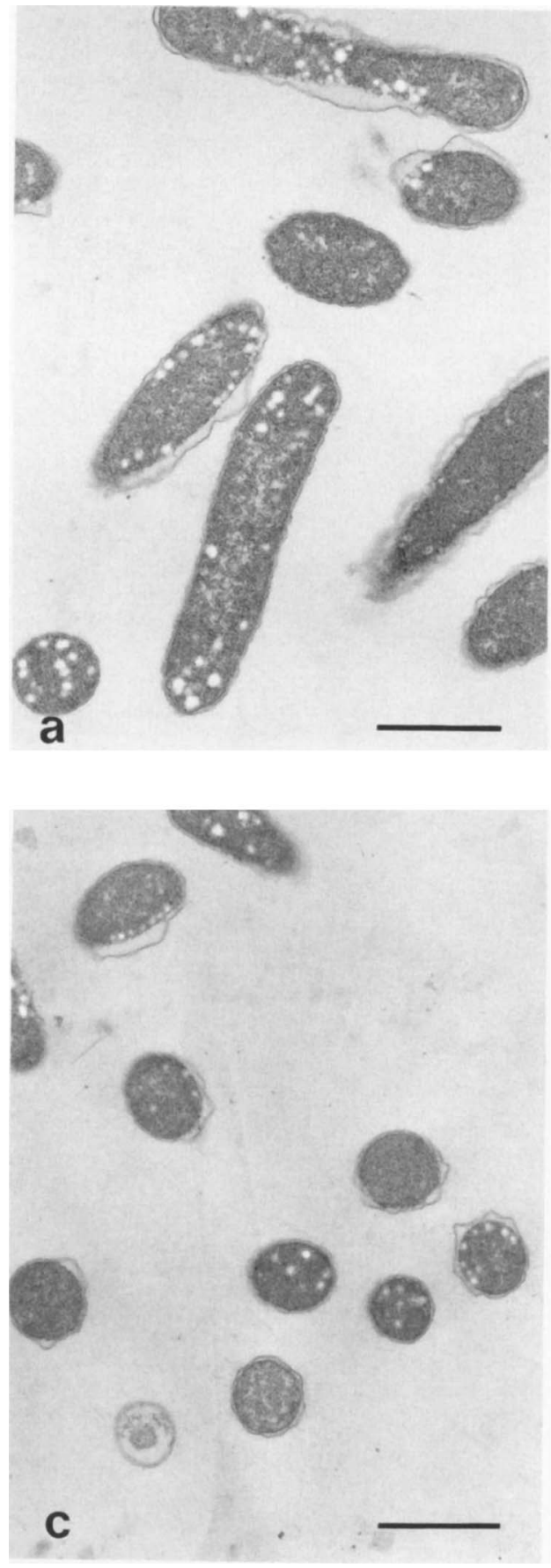
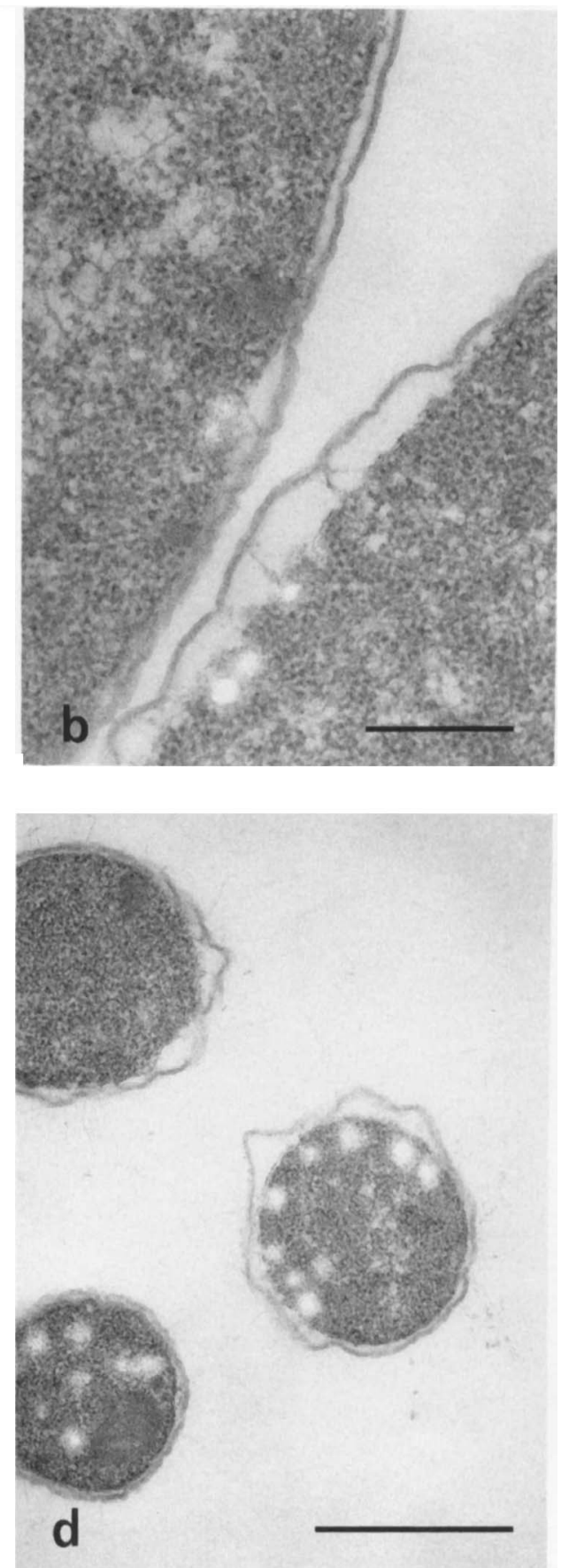

Fig. 2. Ultrathin sections of log phase E. cloacae NCTC 10005 grown in Iso-Sensitest broth containing: a,b, trimethoprim $12 \cdot 5 \mu \mathrm{g} / \mathrm{ml} ; \mathbf{c}, \mathbf{d}$,

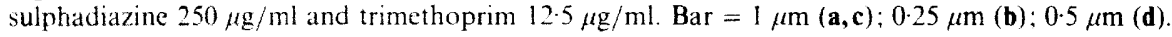

broth at $37^{\circ} \mathrm{C}$ and incubated for $4 \mathrm{~h}$ in a water bath with shaking at 100 oscillations $/ \mathrm{min}$. The bacteria were then centrifuged and the cell pellets were washed with HEPES buffer ( $\mathrm{pH} 7.2)$ and resuspended in the same volume of buffer solution. Lysozyme was added to give a concentration of $50 \mu \mathrm{g} / \mathrm{ml}$ followed by disodium edetate to a concentration of $0.1 \mathrm{~mm}$. The action of disodium edetate was quenched after 45,60 and $90 \mathrm{~s}$. respectively. by the addition of sufficient $\mathrm{MgCl}_{2}$ to achieve a concentration of $40 \mathrm{~mm}$. After the lysozyme had reacted with the cells for $4 \mathrm{~min}$ at $20^{\circ} \mathrm{C}$, the suspensions were centrifuged and prepared for electronmicroscopy as described above.

\section{Determination of bacterial viability}

Viable counts were determined by an overdried agar plate counting method. From a log phase culture 10$\mathrm{ml}$ volumes were added to three flasks containing $90 \mathrm{ml}$ of Iso-Sensitest broth with and without the appropriate antibacterial agent. Viable counts were determined after exposure to the antibacterial agents for $30 \mathrm{~min}, 1 \mathrm{~h}, 2 \mathrm{~h}, 3 \mathrm{~h}, 4 \mathrm{~h}$ and $5 \mathrm{~h}$. p-Aminobenzoic acid $50 \mu \mathrm{g} / \mathrm{ml}$ was incorporated into the Iso-Sensitest agar to antagonise any sulphadiazine or trimethoprim which could have been present in low concentrations in the cells, since $p$-aminobenzoic acid at appropriate 
concentrations not only blocks the antibacterial activity of sulphadiazine but also that of trimethoprim (unpublished results).

\section{Results}

\section{Electronmicroscopy}

Fig. 1 shows the appearance of normal log phase cells of E. cloacae NCTC 10005.

After exposure to sulphadiazine $250 \mu \mathrm{g} / \mathrm{ml}$, at least $50 \%$ of the bacteria exhibited electron-transparent areas devoid of ribosomes (holes) clearly visible within the cytoplasm (fig. 1c). Also, the gap between the cytoplasmic and outer membranes appeared larger and less electron-dense (fig. 1d).

Approximately two-thirds of bacteria exposed to trimethoprim $12.5 \mu \mathrm{g} / \mathrm{ml}$ had holes similar to those seen in the sulphadiazine-treated bacteria (fig. 2a). In addition, there was partial detachment of the outer membrane from the cytoplasmic membrane in most of the bacteria. The membrane generally appeared to be unbroken although detached; however, where the holes were adjacent to the cytoplasmic membrane the membrane often appeared to be broken. Higher magnification showed that only certain areas of the cytoplasmic membrane remained connected to the outer membrane (fig. 2b).

When $E$. cloacae NCTC 10005 was exposed to the combination of sulphadiazine $250 \mu \mathrm{g} / \mathrm{ml}$ and trimethoprim $12.5 \mu \mathrm{g} / \mathrm{ml}$ all the bacteria exhibited damage (fig. $2 \mathrm{c}$ and d).

Fig. 3 shows that brief exposure to disodium edetate plus lysozyme had an effect on the morphology of the

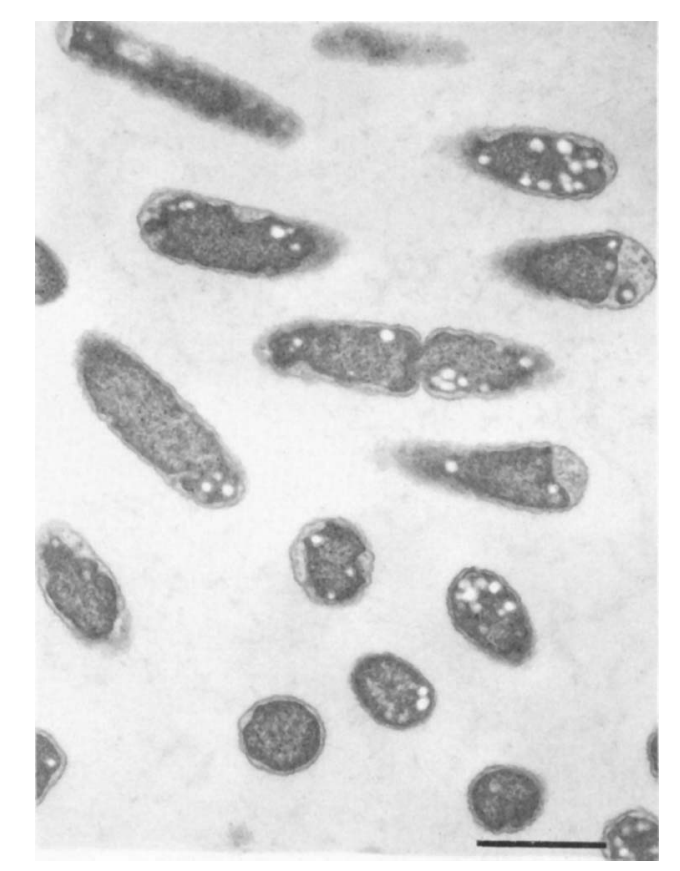

Fig. 3. Ultrathin section of log phase E. cloacae NCTC 10005 treated with disodium edetate and lysozyme for $90 \mathrm{~s}$. Bar $=1 \mu \mathrm{m}$.

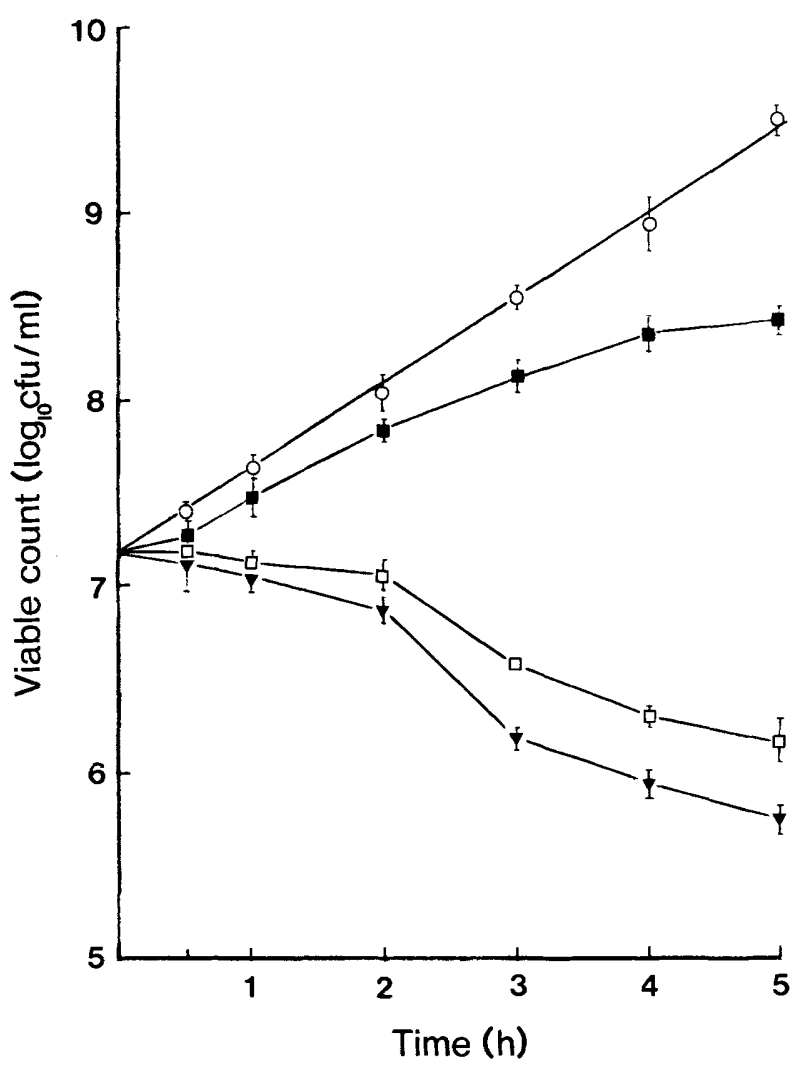

Fig. 4. Viable counts of E. cloacae NCTC 10005 in Iso-Sensitest broth at $37^{\circ} \mathrm{C}$. $\bigcirc$ Control; sulphadiazine $250 \mu \mathrm{g} / \mathrm{ml} ; \square$ trimethoprim $12.5 \mu \mathrm{g} / \mathrm{ml} ; \quad \boldsymbol{\nabla}$ sulphadiazine $250 \mu \mathrm{g} / \mathrm{ml}$ plus trimethoprim $12.5 \mu \mathrm{g} / \mathrm{ml}$.

E. cloacae NCTC 10005 strikingly similar to that of the antimetabolites.

\section{Viable counts}

Sulphadiazine $250 \mu \mathrm{g} / \mathrm{ml}$ slowed the replication of the inoculum of $10^{7} \mathrm{cfu} \log$ phase $E$. cloacae $/ \mathrm{ml}$ after several hours. Trimethoprim $12.5 \mu \mathrm{g} / \mathrm{ml}$ caused a $10-$ fold fall in viable count after $5 \mathrm{~h}$, an effect that was enhanced in the presence of sulphadiazine $250 \mu \mathrm{g} / \mathrm{ml}$ (fig. 4). After $24 \mathrm{~h}$ the viable counts were $10^{9} \mathrm{cfu} / \mathrm{ml}$ (sulphadiazine), $3 \times 10^{7} \mathrm{cfu} / \mathrm{ml}$ (trimethoprim), and $3 \times 10^{5} \mathrm{cfu} / \mathrm{ml}$ (sulphadiazine plus trimethoprim).

\section{Discussion}

Thin sections of E. cloacae NCTC 10005 exposed to sulphadiazine and trimethoprim or disodium edetate plus lysozyme showed electron-transparent areas devoid of ribosomes in the bacterial cytoplasm. Ciprofloxacin can cause similar damage to Escherichia coli. ${ }^{9}$ It may be assumed that protein synthesis would be affected by such damage.

Disodium edetate plus lysozyme causes hydrolysis of the peptidoglycan layer of gram-negative bacteria and morphological effects on Pseudomonas fluorescens similar to those shown here. ${ }^{10}$ The similarity between the effects of lysozyme and the antifolate drugs 
suggests that trimethoprim. and to a lesser extent sulphadiazine. may have an additional effect on the production of peptidoglycan in E. cloacae. It is likely that the enhanced effect of the combination of sulphadiazine and trimethoprim is due to increased uptake into damaged bacterial cells as suggested previously.' "

Viable counts of cultures treated in exactly the same way as those from which the electronmicrographs were prepared indicate that, although sulphadiazine $250 \mu \mathrm{g} / \mathrm{m} /$ merely inhibited growth of log phase cells of $E$. cloaca over a 5 -h period, it nevertheless increased the bactericidal activity of trimethoprim $12.5 \mu \mathrm{g} / \mathrm{ml}$ within $2 \mathrm{~h}$ and throughout the 5 -h period. Moreover. inhibition by sulphadiazine and the bactericidal effect of trimethoprim were short in duration but the effect of the combination was longer lasting.

There is considerable controversy about the interation between sulphadiazine and trimethoprim against sulphadiazine-resistant cells ${ }^{6}$ and in conditions in which trimethoprim alone is able to halt bacterial growth completely. "Brumfitt and Hamilton-Miller stated that "synergy does not occur with bacteria that are resistant to sulphonamides" 6 and Greenwood stated "on theoretical grounds one would predict that sulphamethoxazole would be antagonized by the presence of inhibitory concentrations of trimethoprim ". ' However, under the conditions reported here, the presence of sulphadiazine contributed to the overall activity of the combination of sulphadiazine with trimethoprim both against sulphadiazine-resistant cells and also in the situation in which trimethoprim alone had a bactericidal action. While these results cannot be extrapolated directly to the clinical situation they nevertheless provide experimental evidence of potential benefit from the combination of sulphadiazine with trimethoprim.

\section{References}

1. Richards RME. Tallor RB. Xng DKL. An evaluation of the antibacterial activities of combinations of sulfonamides. trimethoprim, dibromopropamidine, and silver nitrate compared with their uptakes by selected hacteria. J Pham S.i 1991:80:861-867.

2. Richatds RME. Xing DKL. Eraluation of synergistic effects of combinations of antibacterials having relevance to treatment of burn wound infections. Int J Pharm 1991: 75 xi $x x$

3. Sing DKL. Investigations of batcterial uptake of chemical agents having relevance to burn wound therapy. PhD Thesis. The Robert Gordon Institute of Technology: Aberdeen. ('AAA 1990.

4. Richards. RME. Xing DKL. Enhancement of antibacterial activits by p-aminohenzocic acid and sulphadiazine. Im $J$ Pham (in press).

5. Hormser GP Keusch GiT Hall RC. Co-trimoxazole (trimethoprim-sulfamethoxazole): an updated review of its antibacterial activity and clinical efficacy. Drugs 1982: 24 $+5951 x$

6. Brumfitı W, Hamilton-Miller JMT. Co-trimoxazole or trimethoprim alone? A viewpoint on their relative place in therapy. Drugs 1982: 24: 453-458.

7. Greenwood D. Trimethoprim plus sulphamethoxazole: synergic or antagonistic combination? In: Woodbine $\mathrm{M}$ (ed) Antibiotics and antibiosis in agriculture with special reference to synergism. London. Butterworths. 1977: 8 ? 88

8. Bushby SRM. Synergy of trimethoprim and sulphonamides: History and current status. In: Woodbine $M$ (ed) Antibiotics and antibiosis in agriculture with special reference to synergism. London, Butterworths. 1977: 64-81.

9. Lorian V. Effect of low antibiotic concentrations on bacteria: effects on ultrastructure, virulence, and susceptibility to immunodefenses. In: Lorian $\mathrm{V}$ (ed) Antibiotics in laboratory medicine, 2 nd edn. London, Williams and Wilkins. 1986: $596 \cdot 688$.

10. Thornley MJ, Sleytr UB. Freeze-etching of the outer membranes of Pseudomonas and Acinetobacter. Arch Microbiol 1974: 100: 409-417. 